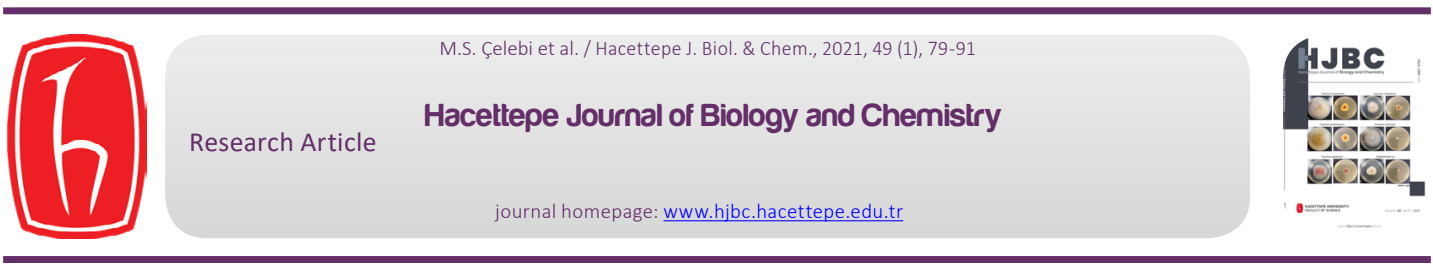

\title{
Electrochemical Synthesis of Cauliflower-Like PtPd@PVF Nanocatalyst for Electrooxidation of Methanol
}

\section{Methanol Elektroyükseltgenmesi İçin Karnabahar-Benzeri PtPd@PVF Nanokatalizörünün Elektrokimyasal Sentezi}

\author{
Mutlu Sönmez Çelebi ${ }^{*}$, Kübra Öztürk ${ }^{\oplus}$, Mehmet Dumangöz ${ }^{\odot}$
}

Department of Chemistry, Faculty of Science and Arts, Ordu University, Ordu, Turkey.

\begin{abstract}
n this study, a bimetallic catalyst consisting of Pt and Pd nanoparticles supported on poly(vinylferrocene), i.e., PtPd@PVF was electrochemically prepared on pencil graphite electrode to improve the catalytic properties of previously developed Pt@PVF catalyst. $\mathrm{K}_{2} \mathrm{PtCl}_{4}$ and $\mathrm{K}_{2} \mathrm{PdCl}_{4}$ were used as the metal precursors in order to disperse the Pt and Pd onto the conducting polymer support by cyclic voltammetry technique. Electrochemical and chemical reduction methods were compared for the reduction of Pt and Pd complexes. The prepared catalyst system was electrochemically characterized by cyclic voltammetry. Physical characterization of the catalyst was performed by recording scanning electron microscopy images and energy dispersive X-ray spectrum. The PtPd@PVF catalyst showed superior catalytic activity towards electrooxidation of methanol compared to the monometallic Pt/PVF catalyst.
\end{abstract}

\section{Key Words}

Poly(vinylferrocene) ; bimetallic catalyst ; methanol oxidation ; Pt Pd nanoparticles.

\section{öz}

\begin{abstract}
Q u çalışmada daha önce geliştirilmiş olan Pt@PVF katalizörünün katalitik özelliklerinin geliştirilmesi için kalem grafit elektrot üzerinde poli(vinilferrosen)-destekli Pt ve Pd bimetalik katalizörü (PtPd@PVF) elektrokimyasal olarak hazırlanmıştır. Pt ve $\mathrm{Pd}$ kaynağı olarak $\mathrm{K}_{2} \mathrm{PtCl}_{4}$ ve $\mathrm{K}_{2} \mathrm{PdCl}_{4}$ kullanılmış ve metallerin iletken polimer yüzeyine disperse edilmesi için dönüşümlü voltametri tekniği kullanılmıştır. Pt ve Pd komplekslerinin indirgenmesi için elektrokimyasal ve kimyasal indirgeme yöntemleri karşılaştırılmıştır. Hazırlanan katalizör sisteminin elektrokimyasal karakterizasyonu için dönüşümlü voltametri kullanılmış olup fiziksel karakterizasyon içinse taramalı elektron mikroskobu görüntüleri ve enerji dağılımlı X-ışınları spektrumu kullanılmıştır. Monometalik Pt@PVF katalizörü ile karşılaştırıldı̆ı̆nda, PtPd@PVF katalizörünün metanolün elektroyükseltgenmesi için daha yüksek katalitik aktivite gösterdiği gözlenmiştir.
\end{abstract}

\section{Anahtar Kelimeler}

Poli(vinilferrosen) ; bimetalik katalizör ; metanol yükseltgenmesi ; Pt Pd nanopartikülleri. 


\section{INTRODUCTION}

Re ecently, fuel cells are considered as promising energy sources for the future as alternatives to traditional systems for many reasons. For instance, the harmful effects of the current combustion-based technologies contribute to many global concerns such as climate change, ozone layer depletion, acidic rains, etc Furthermore, these technologies are mainly dependent on the limited supplies of fossil fuels. On the other hand, fuel cells have the potential to provide efficient and clean energy conversion as they are compatible with renewable sources and modern energy carriers for sustainable development and energy security [1]. During the operation of a fuel cell, the chemical energy of the fuel (hydrogen, methanol, ethanol, formic acid, etc.) and the oxidant (oxygen gas or hydrogen peroxide) is catalytically converted to electricity. Polymer electrolyte fuel cells, also known as Proton Exchange Membrane Fuel Cells (PEMFCs), are considered as one of the most promising alternative fuel cell systems due to their high efficiency and low emissions [2].

In today's world, the increasing demand for portable and mobile devices such as cell phones and laptop computers create a demand for better power sources compared to traditional lithium and nickel based rechargeable battery systems due to their limited energy density. Furthermore, a rechargeable battery requires an external electrical power source for recharging which is a substantial limitation to the mobility of a portable device. For these reasons, PEMFCs are regarded as promising alternatives to rechargeable batteries [3]. Theoretically, a PEMFC using hydrogen as the fuel is the cleanest renewable energy source. However, hydrogen - as a fuel - usually needs to be stored under high pressure and poses transport and storage problems not to mention its flammability and high cost [4]. Compared to hydrogen - fed fuel cells, which have a reforming unit or low capacity in the hydrogen storage tank, a direct methanol fuel cell (DMFC) simplifies the fuel cell system by using methanol as the fuel, which is easily stored and transported [5]. DMFCs have emerged as one of the potential systems, which not only provide clean energy but also offer good commercial viability. Commercial applications of DMFCs like passenger vehicles, generators, chargers and other portable devices such as cell phones and laptop computers are currently available [6-8].
During the operation of a DMFC, methanol and water are oxidized in the anode catalyst layer while the released $\mathrm{H}^{+}$ions react with oxygen gas producing water in the cathode part:

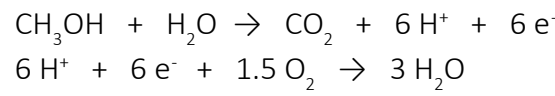

\section{The overall reaction is:}

\section{$\mathrm{CH}_{3} \mathrm{OH}+1.5 \mathrm{O}_{2} \rightarrow \mathrm{CO}_{2}+2 \mathrm{H}_{2} \mathrm{O}$ (3)}

Methanol crossover, which can be defined as diffusion of methanol from the anode to the cathode through the membrane, is one of the most notable technical barriers of DMFCs [3]. Thus, the catalyst layers used in the anode and cathode parts play crucial role for increasing the performance of these fuel cell systems. In order to overcome the limitations associated with the commercialization of fuel cells, researchers focus on improving new materials to increase the efficiency and stability of fuel cell systems while decreasing the overall cost. Commercialization of fuel cells strongly depends on progress of advanced electrode materials with elevated performance. Unfortunately, the most active anode materials for oxidizing the fuel in a fuel cell are platinum (Pt)-based ones which make the fuel cell technology less cost-effective due to the limited supply and high cost of Pt $[2,9]$. To realize the practical application and commercialization of fuel cells, a great number of investigations are carried out for maximizing the activity of Pt-based electrocatalysts over the last decade. Among the successful strategies proposed for this purpose, reducing the size of the catalyst to possess much larger surface area and replacing Pt with Ptbased metallic alloys to reduce cost and increase the activity are remarkable [10]. Alloying two metals results in the formation of heteroatom bonds and geometric effects causing new electronic structures to appear in bimetallic nanoparticles. Also due to the synergistic effect of combining two functional metals, bimetallic alloy nanoparticles demonstrate enhanced electrocatalytic performance with respect to monometallic nanoparticles and hence attract more and more attention [11-13]. Among the metals utilized with Pt to prepare a bimetallic catalyst, palladium (Pd) is not only less expensive and more abundant than Pt, but also exhibits high activity for many catalytic reactions. In many cases, PtPd bimetallic catalysts show increased activity and improved stability when compared with monometallic Pt or Pd catalysts $[14,15]$. Pt-Pd bimetallic catalysts were recently proved to have enhanced activity towards catalytic reactions involved in DMFCs i.e. methanol oxidation 
[16-22] and oxygen reduction [23,24], and have been successfully applied to electrochemical sensors [25-27]. Another strategy to enhance the catalytic performance of nanoparticle-based catalysts is to deposit metal nanoparticles onto a suitable solid matrix designated as "support". Supported metal nanoparticles are known to show improved stability and higher catalytic activity compared to unsupported ones. Good electrical conductivity and large surface area are the main characteristics of an ideal catalyst support. The solid support also serves to reduce the amount of the catalyst used and in some cases improves the catalyst performance and durability by reducing catalyst poisoning $[6,28]$. Recently, carbon-based materials such as commercial carbon supports [29-31], graphene [32,33] and carbon nanotubes $[18,34]$ have been successfully combined with Pt-Pd bimetallic catalysts as well as metal oxides $[35,36]$ and conducting polymers $[37,38]$. The electrical conductivity and the porosity are two important features of a catalyst support. Therefore, the nature of the support material directly affects the catalytic activity due to the interaction effect between the support and the bimetallic catalyst. Moreover, the stability of the catalyst support has to be taken into account for development of new substrates [39]. Among the support materials, conducting polymers have attracted attention recently due to their advantages such as high accessible surface area, low resistance, and high stability together with their conductive and stable structure [2,40-42]. As a redox type conducting polymer, poly(vinylferrocene) (PVF) serves as a favorable agent for electrode modifications with desired surface properties. Advantages of using PVF for modification are mainly simple electrochemistry with a reversible one-electron process, high stability, and ease of deposition of thin films [43].

Among the methods applied for the preparation of metal nanocatalysts, electrochemical methods have the advantages of simplicity, low cost and ease of control during the procedure by simply controlling the experimental parameters [44-49]. Herein, we describe the preparation and characterization of PtPd@PVF nanocatalyst where Pt and Pd nanoparticles are electrochemically dispersed onto the conducting PVF film. $\mathrm{Pt}$ and $\mathrm{Pd}$ were immobilized in the polymer matrix by cyclic voltammetry technique from aqueous solutions of $\mathrm{K}_{2} \mathrm{PtCl}_{4}$ and $\mathrm{K}_{2} \mathrm{PdCl}_{4}$ respectively prior to chemical or electrochemical reduction. The PtPd@PVF catalyst showed superior catalytic activity towards electrooxidation of methanol compared to the monometallic Pt/ PVF catalyst.

\section{MATERIALS and METHODS}

\section{Reagents and instruments}

Poly(vinylferrocene) was synthesized according to the procedure described by Aso et. al. [50]. Vinylferrocene was obtained from Sigma-Aldrich. 2,2-Azo-bis(2methyl-propionitrile) (AIBN) was obtained from Alfa. Tetra-N-butyl ammonium perchlorate (TBAP) ( $\geq 99.0 \%)$ was purchased from Fluka. Methylene chloride (HPLC grade), $\mathrm{H}_{2} \mathrm{SO}_{4}$ and $\mathrm{CH}_{3} \mathrm{OH}$ were obtained from SigmaAldrich. Hydrazine solution was diluted from $80 \%$ aqueous solution of hydrazine hydrate (Merck). $\mathrm{K}_{2} \mathrm{PtCl}_{4^{\prime}}$ $\mathrm{K}_{2} \mathrm{PdCl}_{4}$ were purchased from Sigma-Aldrich and used as received.

Solutions were deoxygenated by purging high purity nitrogen gas prior to use in the electrochemical experiments. Triple distilled water was used for aqueous solutions. All experiments were carried out at ambient temperature.

Electrochemical experiments were performed using CHI 600E electrochemical workstation. Scanning electron microscopy (SEM) images were recorded using JEOL model JSM-7001F.

\section{Electrodes}

Electrochemical experiments were carried out in a threeelectrode system glass cell. Four different working electrodes were used: gold disc electrode ( $\mathrm{Au}, 2 \mathrm{~mm}$ in diameter), platinum disc electrode ( $\mathrm{Pt}, 2 \mathrm{~mm}$ in diameter), glassy carbon electrode (GCE, $3 \mathrm{~mm}$ in diameter) and disposable pencil graphite electrode (PGE, $0.5 \mathrm{~mm}$ in diameter). Silver/silver chloride $(\mathrm{Ag} / \mathrm{AgCl})$ and saturated calomel electrodes (SCE) were used as reference electrodes in methylene chloride and aqueous media respectively. A platinum (Pt) wire was used as the counter electrode.

\section{Preparation of PtPd@PVF modified PGE}

On the surface of PGE, PVF-supported PtPd bimetallic nanoparticles were prepared following a facile, four-step procedure: (1) coating PGE with PVF film by constant potential electrolysis, (2) incorporation of Pt species onto the polymer matrix via cyclic voltammetric scans from $2.0 \mathrm{mM}$ aqueous solution of $\mathrm{K}_{2} \mathrm{PtCl}_{4^{\prime}}(3)$ incorporation of $\mathrm{Pd}$ species onto the polymer matrix via cyclic voltammetric scans from $1.0 \mathrm{mM}$ aqueous solution of $\mathrm{K}_{2} \mathrm{PdCl}_{4^{\prime}}$ (4) chemical or electrochemical reduction of $\mathrm{Pt}$ and $\mathrm{Pd}$ species to obtain PVF - supported Pt and Pd nanoparticles. 
During the procedure, the polymer film was deposited onto the working electrode by electrooxidation of 1.0 $\mathrm{mg} \mathrm{mL}-1$ PVF solution in methylene chloride containing $0.1 \mathrm{M}$ TBAP as the supporting electrolyte. The potential was held constant at $+0.7 \mathrm{~V}$ vs. $\mathrm{Ag} / \mathrm{AgCl}$ throughout the electrolysis. The thickness of the polymer film was controlled by the charge passed during electrolysis. As an example, a charge of $1 \times 10^{-3}$ corresponds to $1.32 \times 10^{-6}$ mol of the oxidized PVF per $\mathrm{cm} 2$ (dry thickness of $~ 300$ $\mu \mathrm{m}$, which corresponds to about $3 \times 10^{5}$ layers) [51]. It is worth mentioning that, the physical appearance and porosity of the polymer films prepared using different charge values significantly vary depending on the film thickness and quantity of the polymer. The resulting film is in a porous structure containing $\mathrm{ClO}_{4}^{-}$ions as the counter ion, ferrocene (PVF) and ferrocenium (PVF+) groups [44]. In the second and third steps, the PVF coated electrode was immersed in aqueous solutions of $2.0 \mathrm{mM} \mathrm{K}_{2} \mathrm{PtCl}_{4}$ and $1.0 \mathrm{mM} \mathrm{K}_{2} \mathrm{PdCl}_{4}$ respectively and cyclic voltammetry was applied in order to immobilize the metal complexes in the polymeric matrix. The potential limits were $-0.85-+1.15 \mathrm{~V}$ and $-0.80-+1.00 \mathrm{~V}$ vs $\mathrm{SCE}$ for $\mathrm{K}_{2} \mathrm{PtCl}_{4}$ and $\mathrm{K}_{2} \mathrm{PdCl}_{4}$ respectively. In these steps, the $\mathrm{Pt}$ and $\mathrm{Pd}$ species are incorporated into the polymer matrix in two ways. First, the negatively charged Pt and $\mathrm{Pd}$ complexes, i.e. $\mathrm{PtCl}_{4}{ }^{2-}$ and $\mathrm{PdCl}_{4}{ }^{2-}$, are accumulated in the positively charged polymer matrix via anion exchange with the $\mathrm{ClO}_{4}^{-}$ions present in the polymer film as the counter anion. This anion exchange capability of the PVF film has recently been reported in the litera- ture [52]. Second, within the applied potential window during the cyclic voltammetric scans performed in $\mathrm{K}_{2} \mathrm{PtCl}_{4}$ and $\mathrm{K}_{2} \mathrm{PdCl}_{4}$ solutions, the $\mathrm{Pt}$ and $\mathrm{Pd}$ complexes are electrochemically reduced to some extend and are incorporated into the polymer matrix as Pt and Pd atoms. The resulting film was then subjected to a reduction step to ensure that the Pt and Pd species have been reduced to $\mathrm{Pt}$ and $\mathrm{Pd}$ atoms. Chemical reduction was simply performed by placing the coated electrode in $0.1 \mathrm{M}$ stirred solution of hydrazine at $300 \mathrm{rpm}$. For electrochemical reduction of the complexes, constant potential electrolysis was applied to the coated electrode at $-0.3 \mathrm{~V}$ vs. SCE for $15 \mathrm{~min}$ in $0.5 \mathrm{M} \mathrm{H}_{2} \mathrm{SO}_{4}$ solution. The resulting catalyst denoted as PtPd@PVF was highly active towards electrocatalytic oxidation of methanol.

\section{RESULTS and DISCUSSION}

\section{Optimization of experimental parameters}

In order to obtain the best performance from the catalyst system, we first optimized the experimental conditions during the preparation of PtPd@PVF. Optimum conditions were determined according to the oxidation peak current values recorded during cyclic voltammogram $(\mathrm{CV})$ of $0.5 \mathrm{M} \mathrm{CH}_{3} \mathrm{OH}$ solution containing $0.5 \mathrm{M}$ $\mathrm{H}_{2} \mathrm{SO}_{4}$ between potentials $0.2-0.7 \mathrm{~V}$ vs. SCE with a scan rate of $5 \mathrm{mV} \mathrm{s}^{-1}$

We investigated the influence of the substrate used for

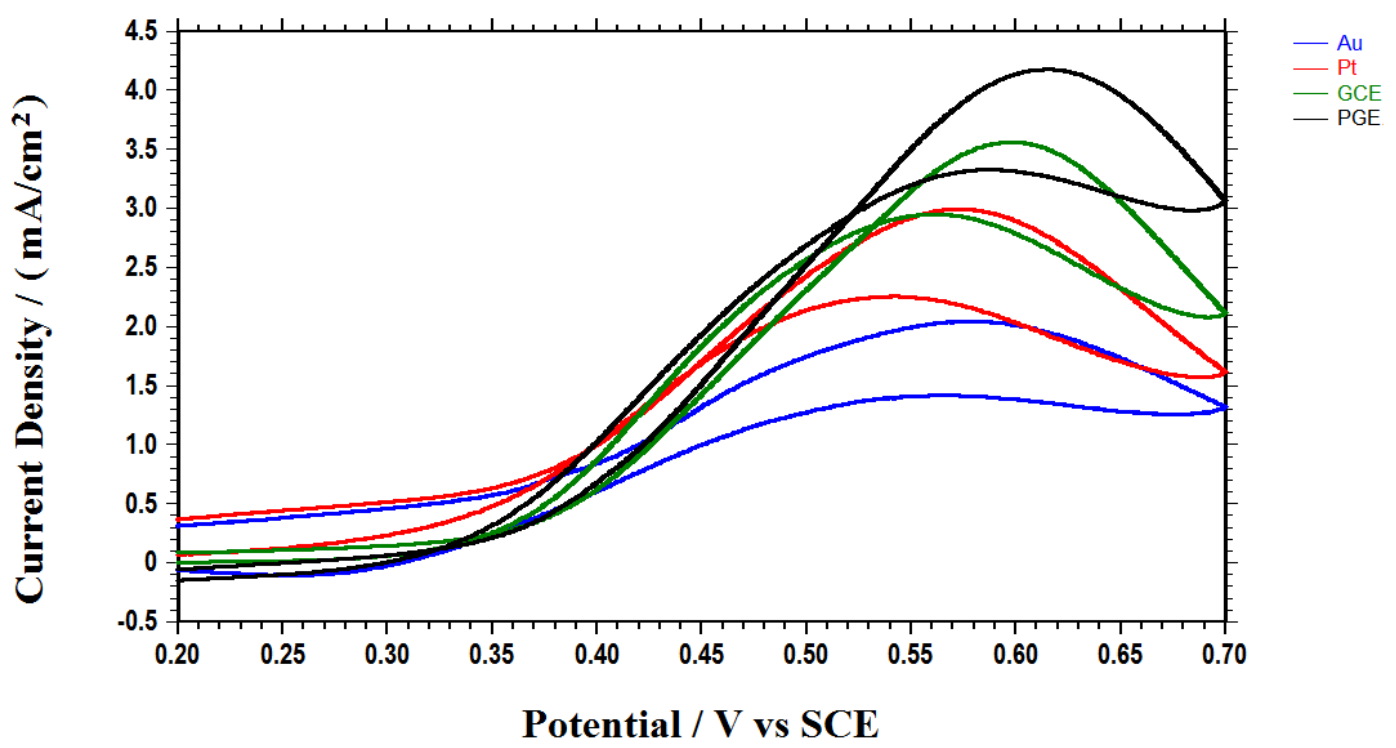

Figure 1. $\mathrm{CVs}$ of $0.5 \mathrm{M} \mathrm{CH} 3 \mathrm{OH}$ solution containing $0.5 \mathrm{M} \mathrm{H} 2 \mathrm{SO} 4$ with $\mathrm{Au}$ (blue), Pt (red), GCE (green) and PGE (black) electrodes coated with PtPd@PVF catalyst. (PW: $0.2-0.7$ V vs. SCE, scan rate: $5 \mathrm{mV} \mathrm{s}^{-1}$ ) 


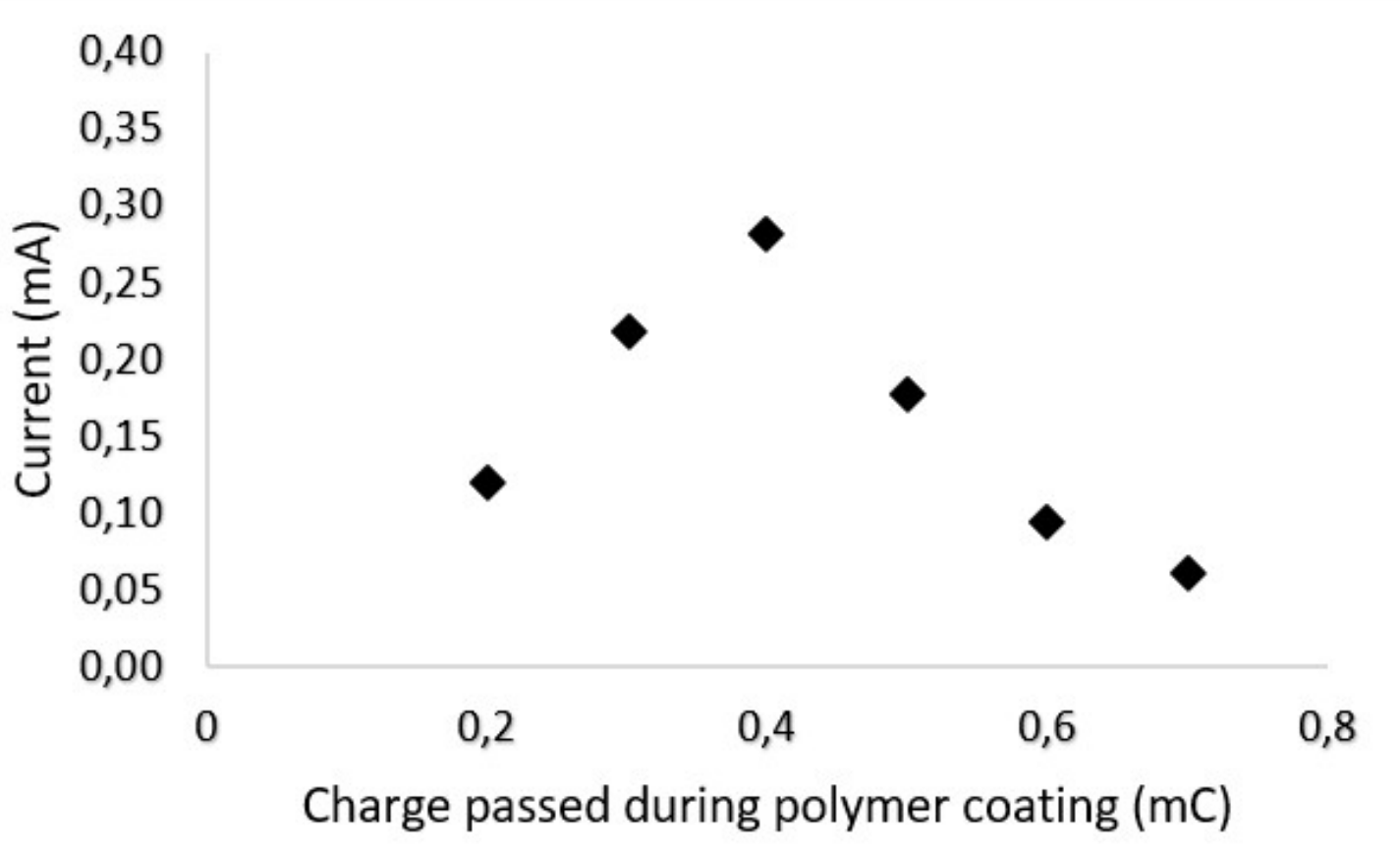

Figure 2. Effect of polymer film thickness (in means of charge passed during polymer coating) on oxidation peak current of methanol.

the working electrode on the oxidation peak current of methanol. For this purpose, we prepared PtPd@PVF catalyst system on $\mathrm{Au}, \mathrm{Pt}, \mathrm{GCE}$ and PGE electrodes and recorded $\mathrm{CV}$ s of $0.5 \mathrm{M} \mathrm{CH}_{3} \mathrm{OH}$ solution in $0.5 \mathrm{M} \mathrm{H}_{2} \mathrm{SO}_{4}$ over the potential window (PW) of $0.2-0.7 \mathrm{~V}$ vs. SCE. In order to obtain comparable results for each electrode material, we have payed attention to equilibrate the quantity of polymer and metal loadings according to the surface area of the electrodes. When we compared the current densities, we observed that maximum peak current density was obtained on a disposable PGE (Figure 1).

To determine the optimum polymer film thickness, we prepared PtPd@PVF catalyst system on PGE using polymer films with different thicknesses. For this purpose, charge passed during electrodeposition of PVF films from the polymer solution was varied from $0.2 \mathrm{mC}$ to $0.7 \mathrm{mC}$. The other experimental conditions were as follows: 30 cycles of $\mathrm{CV}$ in $2.0 \mathrm{mM} \mathrm{K}_{2} \mathrm{PtCl}_{4}$ solution, 10 cycles of $\mathrm{CV}$ in $1.0 \mathrm{mM} \mathrm{K}_{2} \mathrm{PdCl}_{4}$ solution, 60 minutes chemical reduction time in hydrazine. When we compared the CVs, maximum oxidation peak current was obtained with the polymer film corresponding to $0.4 \mathrm{mC}$ charge passed (Figure 2). It is known that, during the coating process of PVF film on the electrode surface, the charge passed (therefore, the thickness of the polymer film) is an important experimental parameter as it directly affects the porosity of the polymer support. As consistent with previous studies, the performance of the catalyst increases up to a thickness and decreases afterwards $[43,44]$. Corresponding CVs can be seen in supplementary content (Figure S1).

To control the quantity and the ratio of Pt and Pd nanoparticles, we used cyclic voltammetry method which enabled controlled incorporation of Pt and Pd species through the control of number of cyclic voltammetric scans. For optimization studies, we immobilized Pt and $\mathrm{Pd}$ complexes from aqueous solutions of $2.0 \mathrm{mM}$ $\mathrm{K}_{2} \mathrm{PtCl}_{4}$ and $1.0 \mathrm{mM} \mathrm{K}_{2} \mathrm{PdCl}_{4}$ without a supporting electrolyte onto PVF films by cyclic voltammetry. Polycyclic voltammograms performed in $\mathrm{K}_{2} \mathrm{PtCl}_{4}$ and $\mathrm{K}_{2} \mathrm{PdCl}_{4}$ are given in Figure $3 \mathrm{a}$ and Figure $3 \mathrm{~b}$ respectively. During the reduction mechanism of $\mathrm{PtCl}_{4}{ }^{2-}$, different $\mathrm{Pt}$ complexes due to the exchange of $\mathrm{H}_{2} \mathrm{O}$ as a ligand coordinating the Pt metal are expected [53]. Therefore, oxidation and reduction peaks associated to these species are observed in the $\mathrm{CV}$ of the $\mathrm{K}_{2} \mathrm{PtCl}_{4}$ molecule. On the other hand, during the reduction mechanism of $\mathrm{PdCl}_{4}{ }^{2-}$ complex, dis- 
(a)

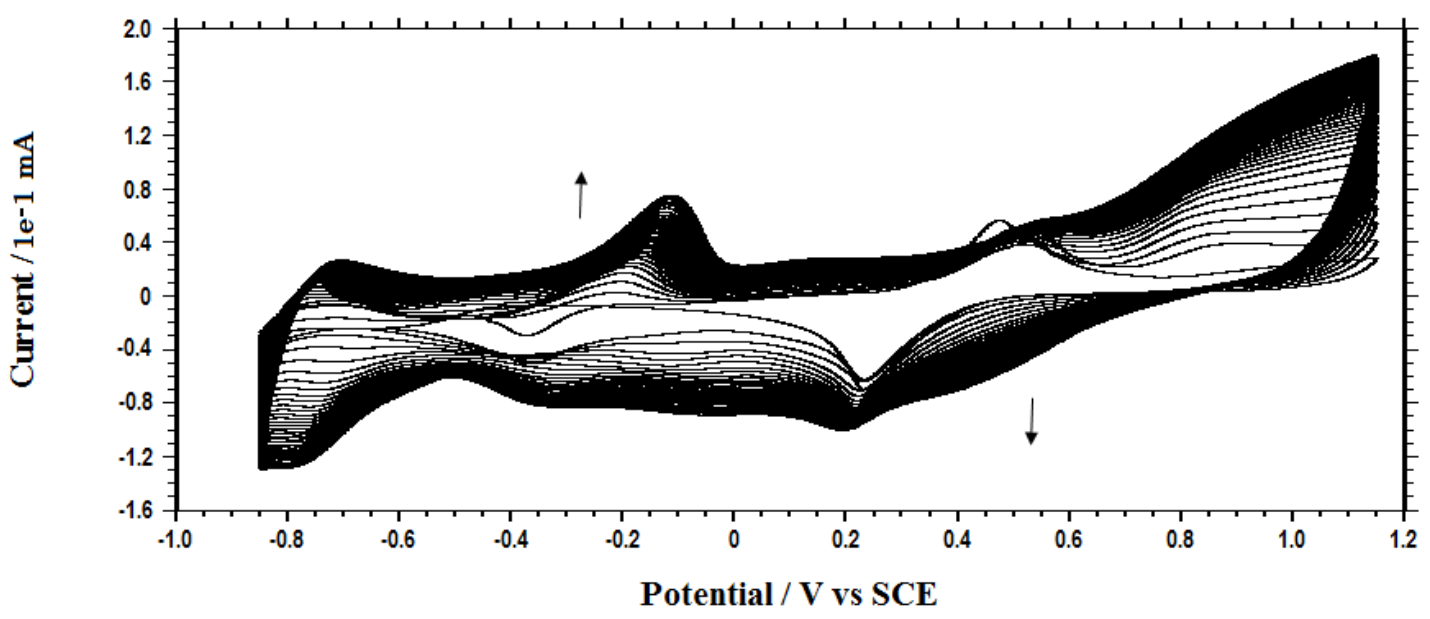

(b)

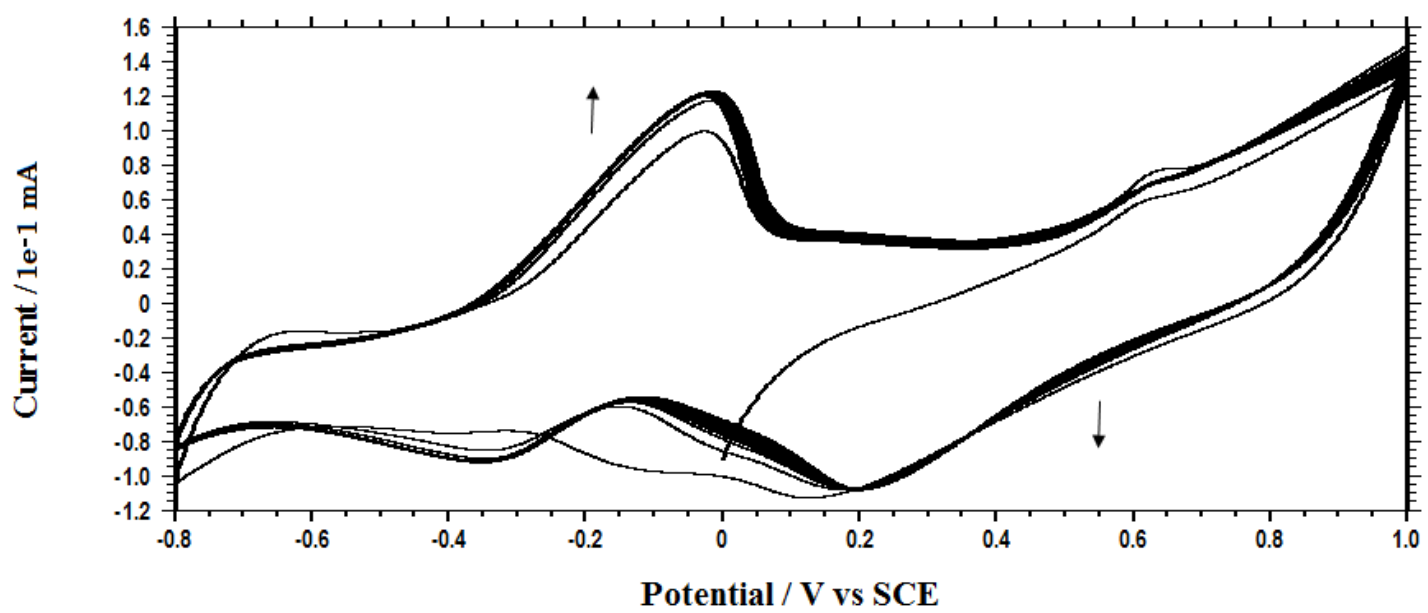

Figure 3. Polycyclic voltammograms performed in (a) $\mathrm{K}_{2} \mathrm{PtCl}_{4}$ (PW: $-0.85-+1.15 \mathrm{~V}$ vs. SCE, scan rate: $100 \mathrm{mV} \mathrm{s}^{-1}$ ) and (b) $\mathrm{K}_{2} \mathrm{PdCl}_{4}$ (PW: $-0.80-+1.00$ V vs. SCE, scan rate: $100 \mathrm{mV} \mathrm{s}^{-1}$ ) for immobilization of Pt and Pd species onto the PVF matrix. 
(a)

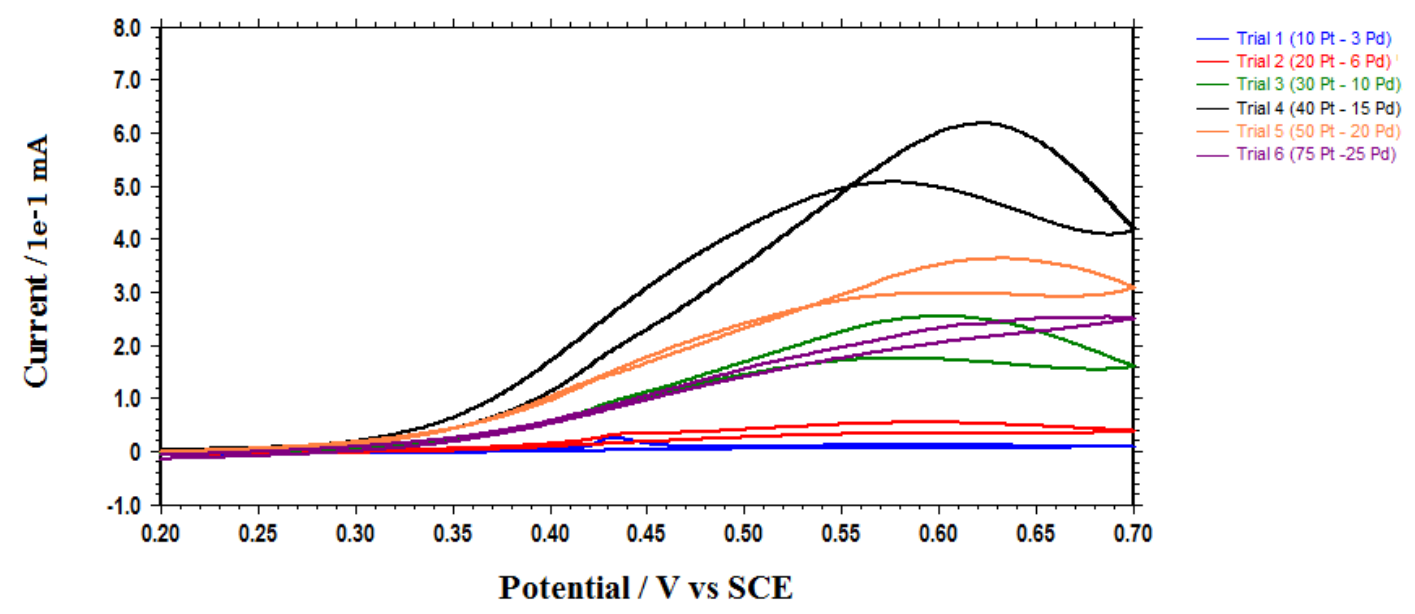

(b)

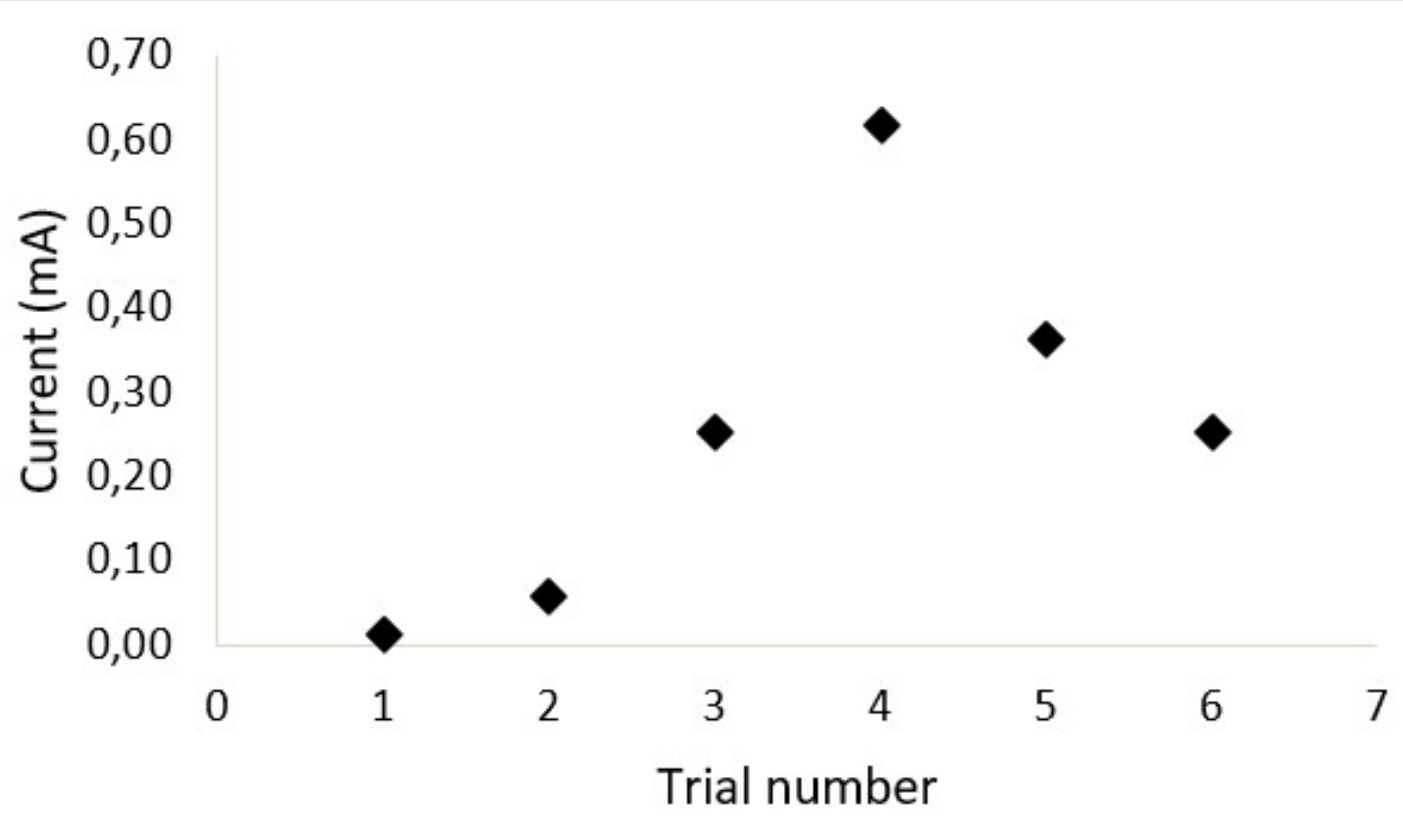

Figure 4. (a) $\mathrm{CVs}$ of $0.5 \mathrm{M} \mathrm{CH}_{3} \mathrm{OH}$ solution containing $0.5 \mathrm{M} \mathrm{H}_{2} \mathrm{SO}_{4}$ on PtPd@PVF catalyst having various amounts of Pt and Pd.

(PW: $0.2-+0.7 \mathrm{~V}$ vs. SCE, scan rate: $5 \mathrm{mV} \mathrm{s}^{-1}$ ) (b) Corresponding plot representing current values vs. varying amounts of Pt and Pd. 


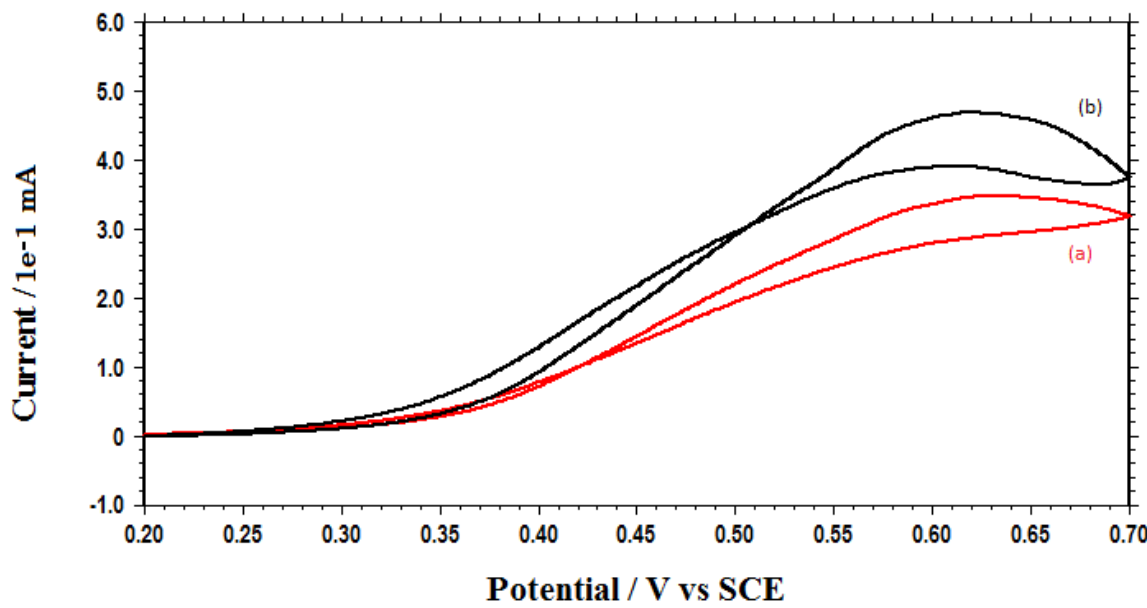

(a) Electrochemical reduction

(b) Chemical reduction

Figure 5. $\mathrm{CVs}$ of $0.5 \mathrm{M} \mathrm{CH}_{3} \mathrm{OH}$ solution containing $0.5 \mathrm{M} \mathrm{H}_{2} \mathrm{SO}_{4}$ on PtPd@PVF catalyst prepared by (a) Electrochemical reduction, (b) Chemical reduction methods. (PW: $0.2-+0.7 \mathrm{~V}$ vs. SCE, scan rate: $5 \mathrm{mV} \mathrm{s}^{-1}$ ).

Table 1. Comparison of electrochemical and chemical reduction methods.

\begin{tabular}{cccc}
\hline Reduction method & Onset potential & Oxidation peak potential & Oxidation peak current \\
\hline Electrochemical reduction & $0.275 \mathrm{~V}$ & $0.630 \mathrm{~V}$ & $0.98 \times 10^{-2} \mathrm{~A}$ \\
\hline Chemical reduction & $0.265 \mathrm{~V}$ & $0.620 \mathrm{~V}$ & $1.30 \times 10^{-2} \mathrm{~A}$ \\
\hline
\end{tabular}

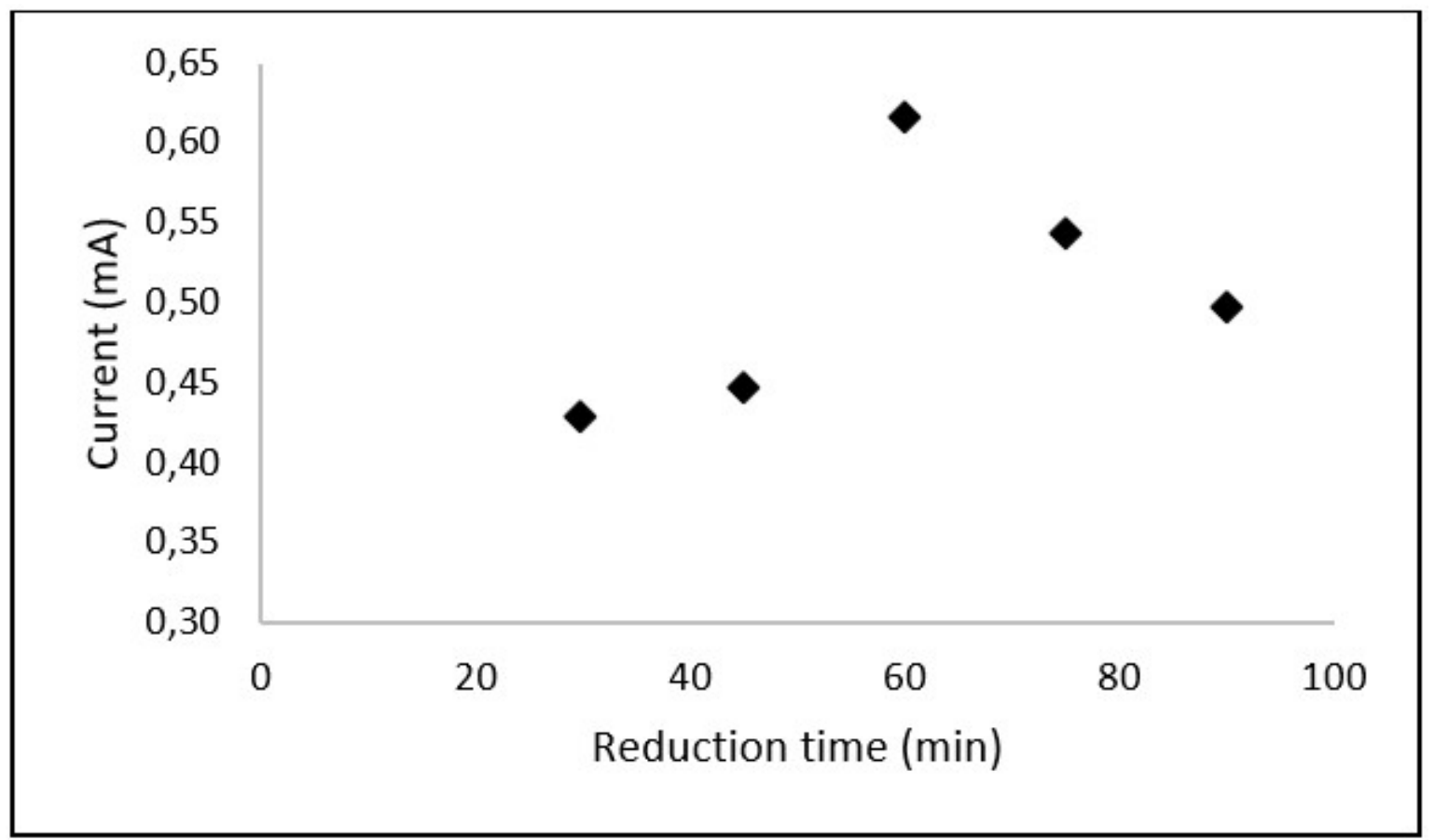

Figure 6. Effect of chemical reduction time on oxidation peak current of methanol. 
sociation of the complex occurs sequentially forming Pd species such as $\mathrm{PdCl}_{3}{ }^{-}$and $\mathrm{PdCl}_{2}{ }^{2-}$ [54]. As a result, similar to the Pt complex, various oxidation and reduction peak are observed in the CV of the Pd complex.

The amount of $\mathrm{Pt}$ and $\mathrm{Pd}$ deposited onto the polymer film was controlled by the number of cyclic voltammet ric scans in the precursor solutions. The experimental conditions were as follows: $0.4 \mathrm{mC}$ charge passed during electrodeposition of PVF, varying numbers of cyclic voltammetric scans in $\mathrm{Pt}$ and $\mathrm{Pd}$ precursor solutions (Trial 1: $10 \mathrm{Pt}-3 \mathrm{Pd}$; Trial 2: $20 \mathrm{Pt}-6 \mathrm{Pd}$; Trial $3: 30$ Pt - 10 Pd ; Trial 4: $40 \mathrm{Pt}-15 \mathrm{Pd}$; Trial 5: $50 \mathrm{Pt}-20 \mathrm{Pd}$ ; Trial 6: $75 \mathrm{Pt}-25 \mathrm{Pd}$ ) and 60 minutes chemical reduction time in hydrazine. The CVs recorded in methanol solution are given in Figure $4 \mathrm{a}$. When the peak current values are compared, it is clear that best catalytic performance was obtained at Trial 4 where 40 cyclic voltammetric scans in $\mathrm{K}_{2} \mathrm{PtCl}_{4}$ and 15 cyclic voltammetric scans in $\mathrm{K}_{2} \mathrm{PdCl}_{4}$ were applied (Figure $4 \mathrm{~b}$ ). This behavior of the catalyst is consistent with previous studies where the catalyst performance increases up to an optimum metal content and decrease with loading more Pt or Pd $[43,44]$

After immobilization of $\mathrm{PtCl}_{4}{ }_{4}^{2-}$ and $\mathrm{PdCl}_{4}{ }^{2-}$ species onto the polymer matrix, the next step was the reduction of the complexes to obtain Pt and Pd nanoparticles. We payed attention to the reduction procedure as it might control the size and dispersion of the nanoparticles and therefore affect the electrocatalytic activity. We compared elect- rochemical and chemical reduction methods by means of oxidation peak potential of methanol. For electrochemical reduction, we deposited PVF film to the surface of the PGE (corresponding to a charge of $0.4 \mathrm{mC}$ ) and then applied 40 cyclic voltammetric scans in $2.0 \mathrm{mM} \mathrm{K}_{2} \mathrm{PtCl}_{4}$ and 15 cyclic voltammetric scans in $1.0 \mathrm{mM} \mathrm{K}_{2} \mathrm{PdCl}_{4}$. The reduction of the complexes was performed in stirred $0.5 \mathrm{M} \mathrm{H}_{2} \mathrm{SO}_{4}$ solution at a constant potential of $-0.3 \mathrm{~V}$ vs. SCE for $15 \mathrm{~min}$ and the resulting catalyst was used for recording $\mathrm{CV}$ of $0.5 \mathrm{M}$ $\mathrm{CH}_{3} \mathrm{OH}$ solution (Figure 5a). The same experimental conditions were applied for the chemically reduced catalyst and the reduction was then performed in stirred $0.1 \mathrm{M}$ hydrazine solution for 60 min before recording the $\mathrm{CV}$ of the methanol solution (Figure 5b). According to the data given in Table 1 , chemical reduction method was more favorable than electrochemical reduction by means of onset potential, oxidation peak potential and oxidation peak current values.

We also studied chemical reduction time between 30 and 90 minutes. According to the data obtained from CVs of $0.5 \mathrm{M} \mathrm{CH}_{3} \mathrm{OH}$ solution (see Figure S2), a reduction time of 60 min was determined as the optimum condition for best performance (Figure 6).

\section{Characterization of PtPd@PVF catalyst Electrochemical characterization}

Electrochemical characterization of the bimetallic catalyst was performed by recording CVs of $0.5 \mathrm{M} \mathrm{H}_{2} \mathrm{SO}_{4}$ solution and comparing the CVs for naked PGE, PVF coated PGE, monometallic Pt@PVF catalyst and bimetallic

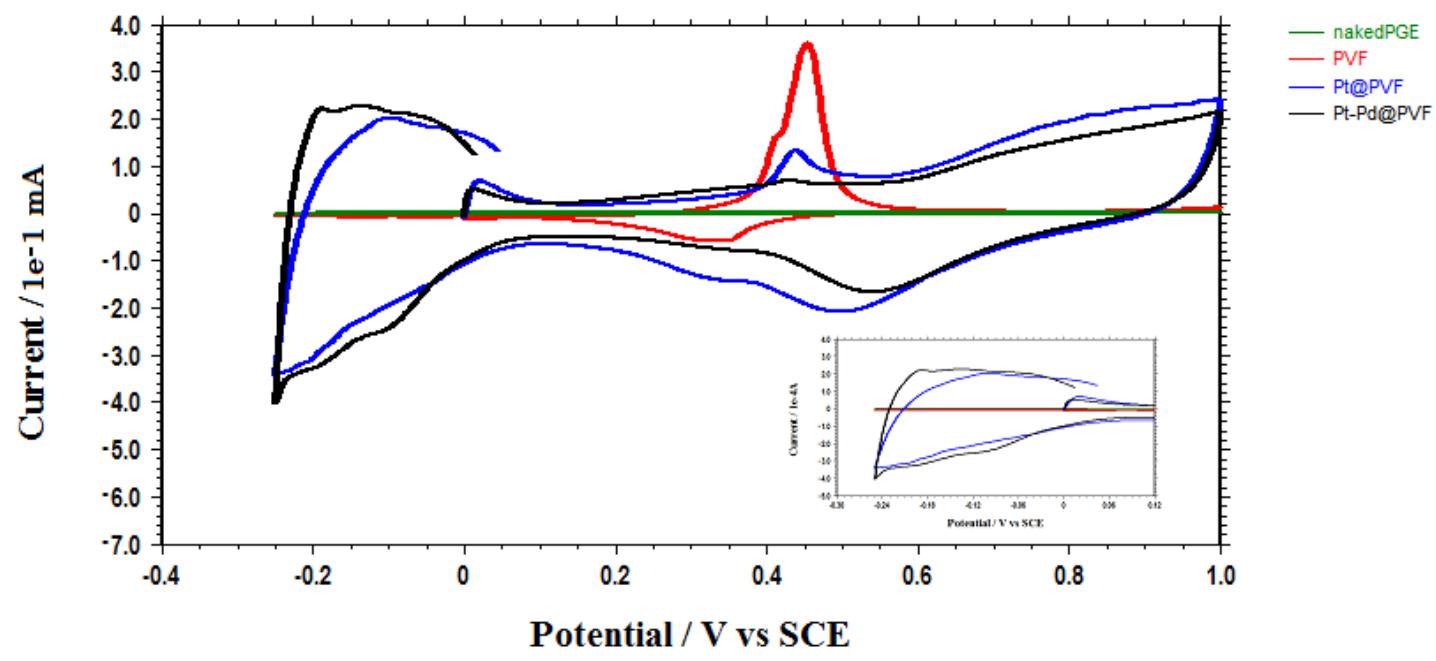

Figure 7. CVs of $0.5 \mathrm{M} \mathrm{H}_{2} \mathrm{SO}_{4}$ recorded with naked PGE (green), PVF coated PGE (red), Pt@PVF modified PGE (blue) and PtPd@PVF modified PGE (black). Inset: negative potential region. (PW: $0.25-+1.0 \mathrm{~V}$ vs. SCE, scan rate: $100 \mathrm{mV} \mathrm{s}^{-1}$ ) 


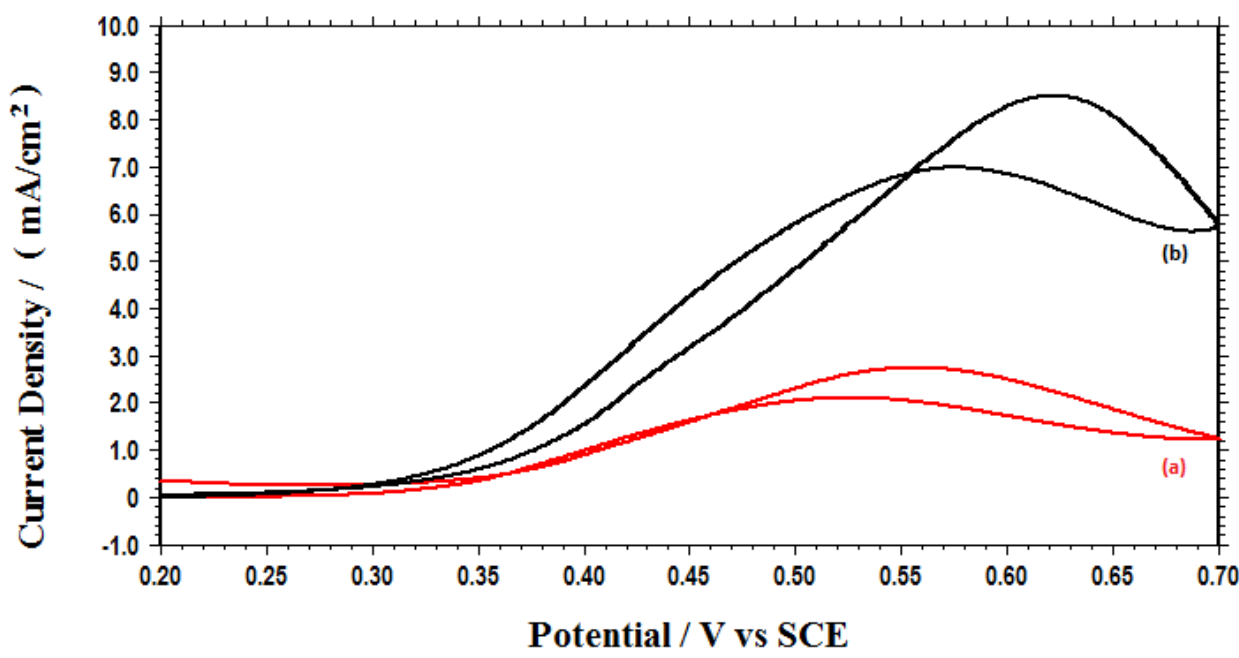

(a) Pt@PVF

(b) PtPd@PVF

Figure 8. CVs of $0.5 \mathrm{M} \mathrm{CH}_{3} \mathrm{OH}$ solution containing $0.5 \mathrm{M} \mathrm{H}_{2} \mathrm{SO}_{4}$ recorded with (a) monometallic Pt@PVF catalyst and (b) bimetallic PtPd@PVF catalyst. (PW: $0.2-+0.7$ V vs. SCE, scan rate: $5 \mathrm{mV} \mathrm{s}^{-1}$ )

PtPd@PVF catalyst on PGE which was prepared using chemical reduction method (Figure 7). It is worth mentioning that the anodic peaks around $0.4 \mathrm{~V}$ vs. SCE for PVF andPt@PVF coated are observed due to the oxidation of the ferrocene form of the polymer to the ferrocenium form.

Between potentials 0.00 and $-0.25 \mathrm{~V}$, oxidation and reduction peaks associated with weakly and strongly adsorbed hydrogen was observed for monometallic and bimetallic catalysts. As expected, no hydrogen peaks were observed with the PVF coated graphite. When monometallic and bimetallic catalyst systems are compared, the bimetallic catalyst had better response with higher peak current values indicating better electrocatalytic activity. This behavior was also supported by behavior of the monometallic and bimetallic catalysts towards oxidation of methanol. Figure 8a shows the CVs of $0.5 \mathrm{M} \mathrm{CH}_{3} \mathrm{OH}$ recorded with Pt@PVF catalyst prepared under optimum experimental conditions using a Pt disc electrode $\left(A=7.85 \times 10^{-3} \mathrm{~cm}^{2}\right)$ according to the method described before [43]. It is clear from the CVs that the bimetallic PtPd@PVF catalyst described in this work is significantly more active towards electrocatalytic oxidation of methanol compared to the monometallic one (Figure 8b).

\section{Physical characterization}

SEM images of both the PVF and the PtPd@PVF catalyst prepared under optimum conditions were recorded on PGE together with EDS patterns and elemental mapping (Figure 9). For comparison, SEM image of naked PGE is given in Figure S3. When we look into the SEM image of the bimetallic catalyst, unlike the structures of monometallic Pt@PVF and Pd@PVF catalysts, a hierarchical structure was observed consisting of well dispersed aggregates of nanosized Pt and Pd atoms $[43,44]$. This feature results in a highly porous character enabling the catalyst to serve as an excellent medium for methanol oxidation reaction (Figure 9a) and the cauliflower-like structure of the catalyst is clearly observed due to aggregation of the nanoparticles (Figure 9b). The recorded EDS spectrum clearly reveals the presence of Pt and Pd atoms in the catalyst together with the Fe atoms existing in the polymer matrix (Figure 9c). Moreover, as shown in the elemental mapping in Figure $9 \mathrm{~d}, \mathrm{Pt}$ and $\mathrm{Pd}$ nanoparticles are well dispersed in the polymer matrix enabling high catalytic activity. 
(a)

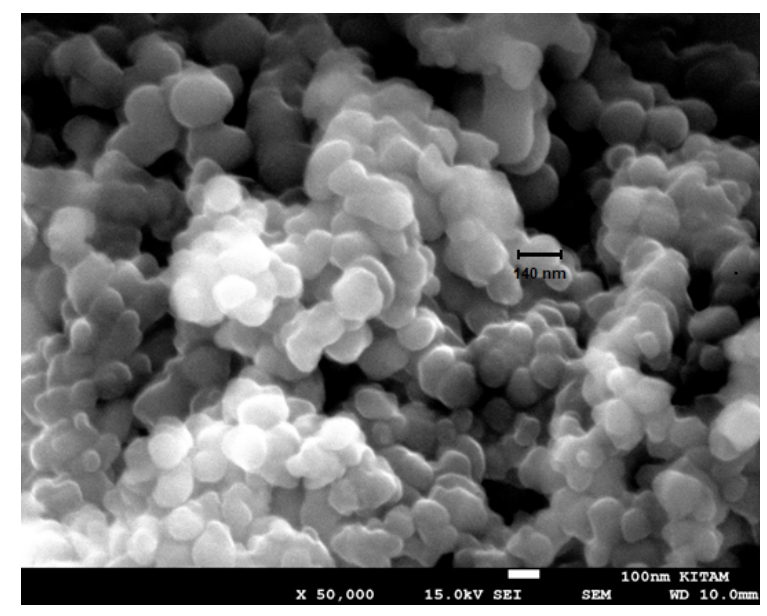

(c)

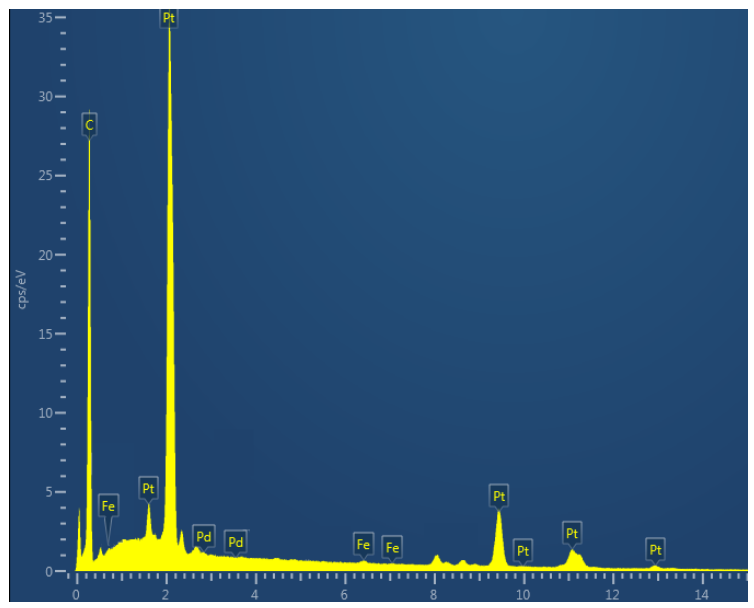

(b)

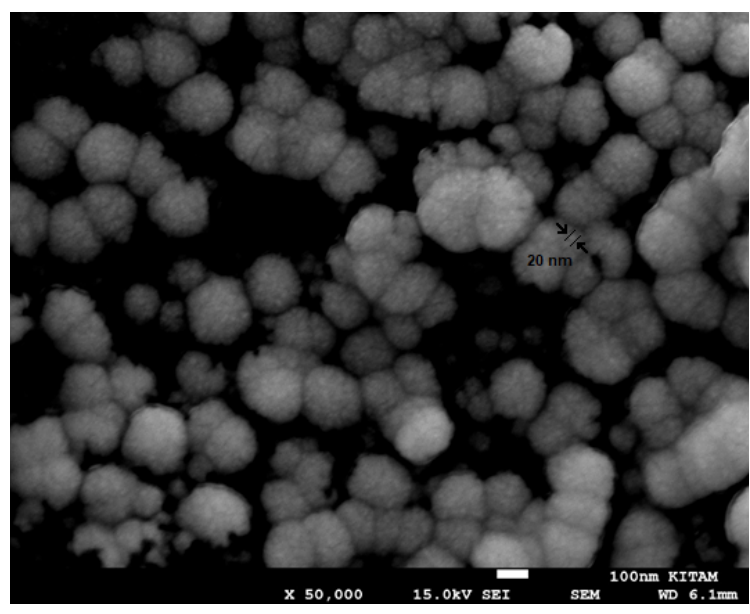

(d)

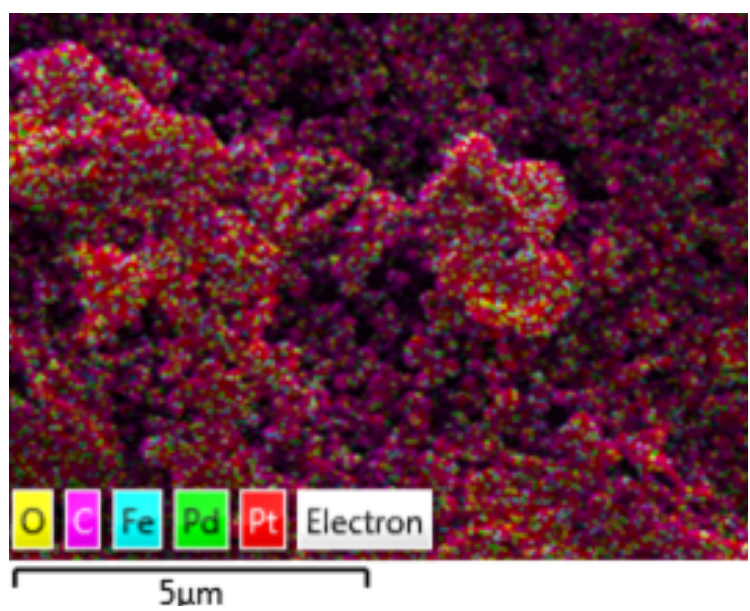

Figure 9. SEM images of (a) PVF coated PGE and (b) PtPd@PVF coated PGE. (c) EDS spectrum and (d) elemental mapping of PtPd@PVF coated PGE.

\section{Conclusions}

We prepared bimetallic PtPd@PVF catalyst on PGE using a facile synthesis route and optimized the experimental conditions to obtain maximum performance towards electrocatalytic oxidation of methanol. Physical characterization of the catalyst indicated formation of cauliflower-like structure and revealed well dispersion of Pt and Pd nanoparticles on the electrode surface. Furthermore, we compared the bimetallic catalyst with monometallic Pt@PVF for methanol oxidation and observed significantly better result with the bimetallic one. The bimetallic catalyst system revealed comparable results for electrocatalytic oxidation of methanol among other bimetallic PtPd catalyst systems [16,19,21]. Having these features, the PtPd@PVF catalyst can be considered and further improved as an anode catalyst system for DMFCs.

Acknowledgements - This work was supported by the Scientific Research Projects Coordination Department of Ordu University (ODUBAP) with grant number: AR1403. 


\section{References}

1. O. Z. Sharaf, M. F. Orhan, An overview of fuel cell technology: Fundamentals and applications, Renew. Sustain. Energy Rev., 32 (2014) 810-853.

2. M. Sönmez Çelebi, Energy Applications: Fuel Cells, in Advanced Electrode Materials (Edited by A. Tiwari, F. Kuralay, L. Uzun), Wiley-VCH, Weinheim (2016) 397-434.

3. X. Li, A. Faghri, Review and advances of direct methanol fuel cells (DMFCs) part I: Design, fabrication, and testing with high concentration methanol solutions, J. Power Sources, 226 (2013) 223-240.

4. B. C. Ong, S. K. Kamarudin, S. Basri, Direct liquid fuel cells: A review, Int. J. Hydrogen Energy, 42 (2017) 10142-10157.

5. H. Liu, C. Song, L. Zhang, J. Zhang, H. Wang, D. P. Wilkinson, A review of anode catalysis in the direct methanol fuel cell, J. Power Sources, 155 (2006) 95-110.

6. [6] S. Sharma, B. G. Pollet, Support materials for PEMFC and DMFC electrocatalysts - A review, J. Power Sources, 208 (2012) 96-119.

7. S. K. Kamarudin, F. Achmad, W. R. W. Daud, Overview on the application of direct methanol fuel cell (DMFC) for portable electronic devices, Int. J. Hydrogen Energy, 34 (2009) 69026916.

8. A. M. Zainoodin, S. K. Kamarudin, W. R. W. Daud, Electrode in direct methanol fuel cells, Int. J. Hydrogen Energy, 35 (2010) 4606-4621.

9. S. Basri, S. K. Kamarudin, W. R. W. Daud, Z. Yaakub, Nanocatalyst for direct methanol fuel cell (DMFC), Int. J. Hydrogen Energy, 35 (2010) 7957-7970.

10. H. Wu, S. Mei, X. Cao, J. Zheng, M. Lin, J. Tang, F. Ren, Y. Du, Y. Pan, H. Gu, Facile synthesis of Pt/Pd nanodendrites for the direct oxidation of methanol, Nanotechnology, 25 (2014) 195702.

11. N. Toshima, H. Yan, Y. Shiraishi, Recent Progress in Bimetallic Nanoparticles: Their Preparation, Structures and Functions, in Metal Nanoclusters in Catalysis and Materials Science: The Issue of Size Control, (Edited by B. Corain, G. Schmid, N. Toshima), Elsevier B.V. (2008) 49-75.

12. M. Xiao, X. Liang, W. Li, Y. Yang, Y. Miao, Synthesis of Ultrafine $\mathrm{Pt} / \mathrm{Pd}$ Bimetallic Nanoparticles and Their Decoration on MWCNTs for Hydrogen Evolution, J. Electrochem. Soc., 162 (2015) H415-H418.

13. K. An, G. A. Somorjai, Nanocatalysis I: Synthesis of Metal and Bimetallic Nanoparticles and Porous Oxides and Their Catalytic Reaction Studies, Catal. Letters, 145 (2015) 233248.

14. H. R. Cho, J. R. Regalbuto, The rational synthesis of Pt-Pd bimetallic catalysts by electrostatic adsorption, Catal. Today, 246 (2015) 143-153.

15. M. Wang, Z. Zheng, J. Liu, C. Wang, Pt-Pd Bimetallic Nanoparticles Decorated Nanoporous Graphene as a Catalytic Amplification Platform for Electrochemical Detection of Xanthine, Electroanalysis, 29 (2017) 1258-1266.

16. X. Chen, Z. Cai, M. Oyama, X. Chen, Synthesis of bimetallic PtPd nanocubes on graphene with $\mathrm{N}, \mathrm{N}$-dimethylformamide and their direct use for methanol electrocatalytic oxidation, Carbon N. Y., 66 (2014) 387-394.

17. N. V. Long, M. Ohtaki, T. D. Hien, J. Randy, M. Nogami, A comparative study of Pt and Pt-Pd core-shell nanocatalysts, Electrochim. Acta, 56 (2011) 9133-9143.

18. E. Kim, H. S. Jeong, B. M. Kim, Efficient chemoselective reduction of nitro compounds and olefins using $\mathrm{Pd}-\mathrm{Pt}$ bimetallic nanoparticles on functionalized multi-wallcarbon nanotubes, Catal. Commun., 45 (2014) 25-29.
19. Z. X. Cai, C. C. Liu, G. H. Wu, X. M. Chen, X. Chen, Green synthesis of Pt-on-Pd bimetallic nanodendrites on graphene via in situ reduction, and their enhanced electrocatalytic activity for methanol oxidation, Electrochim. Acta, 127 (2014) 377-383.

20. Y. Zhang, G. Chang, H. Shu, M. Oyama, X. Liu, Y. He, Synthesis of Pt-Pd bimetallic nanoparticles anchored on graphene for highly active methanol electro-oxidation, J. Power Sources, 262 (2014) 279-285.

21. O. Akyıldırım, G. Kotan, M. L. Yola, T. Eren, N. Atar, Fabrication of bimetallic Pt/Pd nanoparticles on 2-thiolbenzimidazole functionalized reduced graphene oxide for methanol oxidation, Ionics (Kiel)., 22 (2016) 593-600.

22. Y. Y. Chu, Z. B. Wang, Z. Z. Jiang, D. M. Gu, G. P. Yin, Facile synthesis of hollow spherical sandwich PtPd/C catalyst by electrostatic self-assembly in polyol solution for methanol electrooxidation, J. Power Sources, 203 (2012) 17-25.

23. Y. Lim, S. K. Kim, S. C. Lee, J. Choi, K. S. Nahm, S. J. Yoo, P. Kim, One-step synthesis of carbon-supported Pd@Pt/C coreshell nanoparticles as oxygen reduction electrocatalysts and their enhanced activity and stability, Nanoscale, 6 (2014) 4038-4042.

24. J. J. Lv, J. N. Zheng, L. L. Chen, M. Lin, A. J. Wang, J. R. Chen, J. J. Feng, Facile synthesis of bimetallic alloyed Pt-Pd nanocubes on reduced graphene oxide with enhanced eletrocatalytic properties, Electrochim. Acta, 143 (2014) 36-43.

25. X. Chen, X. Tian, L. Zhao, Z. Huang, M. Oyama, Nonenzymatic sensing of glucose at neutral $\mathrm{pH}$ values using a glassy carbon electrode modified with graphene nanosheets and Pt-Pd bimetallic nanocubes, Microchim. Acta, 181 (2014) 783-789.

26. S. Dutta, C. Ray, S. Sarkar, A. Roy, R. Sahoo, T. Pal, Facile Synthesis of Bimetallic Au-Pt, Pd-Pt, and $\mathrm{Au}-\mathrm{Pd}$ Nanostructures: Enhanced Catalytic Performance of Pd-Pt Analogue towards Fuel Cell Application and Electrochemical Sensing, Electrochim. Acta, 180 (2015) 1075-1084.

27. C. X. Yuan, Y. R. Fan, T. Zhang, H. X. Guo, J. X. Zhang, Y. L. Wang, D. L. Shan, X. Q. Lu, A new electrochemical sensor of nitro aromatic compound based on three-dimensional porous Pt-Pd nanoparticles supported by graphene-multiwalled carbon nanotube composite, Biosens. Bioelectron., 58 (2014) 85-91.

28. B. Neppolian, V. Sáez, J. González-García, F. Grieser, R. Gómez, M. Ashokkumar, Sonochemical synthesis of graphene oxide supported Pt-Pd alloy nanocrystals as efficient electrocatalysts for methanol oxidation, J. Solid State Electrochem., 18 (2014) 3163-3171.

29. F. Kadirgan, A. M. Kannan, T. Atilan, S.Beyhan, S. S. Ozenler, S. Suzer, A.Yörür, Carbon supported nano-sized Pt-Pd and Pt-Co electrocatalysts for proton exchange membrane fuel cells, Int. J. Hydrogen Energy, 34 (2009) 9450-9460.

30. R. Kortlever, I. Peters, S. Koper, M. T. M. Koper, Electrochemical CO2Reduction to Formic Acid at Low Overpotential and with High Faradaic Efficiency on CarbonSupported Bimetallic Pd-Pt Nanoparticles, ACS Catal., 5 (2015) 3916-3923.

31. J. Zhang, X. Hu, B. Yang, N. Su, H. Huang, Novel synthesis of PtPd nanoparticles with good electrocatalytic activity and durability, 709 (2017) 588-595.

32. K. Wu, Q. Zhang, D. Sun, X. Zhu, Y. Chen, T. Lu, Y. Tang, Graphene-supported Pd-Pt alloy nanoflowers: In situ growth and their enhanced electrocatalysis towards methanol oxidation, Int. J. Hydrogen Energy, 40 (2015) 6530-6537. 
33. Y. Yang, L. M. Luo, Y. F. Guo, Z. X. Dai, R. H. Zhang, C. Sun, X. $W$. Zhou, In situ synthesis of PtPd bimetallic nanocatalysts supported on graphene nanosheets for methanol oxidation using triblock copolymer as reducer and stabilizer, J. Electroanal. Chem., 783 (2016) 132-139.

34. S. Ghosh, S. Mondal, C. Retna Raj, Carbon nanotubesupported dendritic Pt-on-Pd nanostructures: growth mechanism and electrocatalytic activity towards oxygen reduction reaction, J. Mater. Chem. A, 2 (2014) 2233-2239.

35. A. Zielińska-Jurek, J. Hupka, Preparation and characterization of Pt/Pd-modified titanium dioxide nanoparticles for visible light irradiation, Catal. Today, 230 (2014) 181-187.

36. K. Hassan, A. S. M. Iftekhar Uddin, G. S. Chung, Fast-response hydrogen sensors based on discrete Pt/Pd bimetallic ultrathin films, Sensors Actuators, B Chem., 234 (2016) 435-445.

37. J. Datta, A. Dutta, M. Biswas, Enhancement of functional properties of PtPd nano catalyst in metal-polymer composite matrix: Application in direct ethanol fuel cell, Electrochem. commun., 20 (2012) 56-59.

38. P. Boomi, H. G. Prabu, J. Mathiyarasu, Synthesis, characterization and antibacterial activity of polyaniline/ Pt-Pd nanocomposite, Eur. J. Med. Chem., 72 (2014) 18-25.

39. A. Pinithchaisakula, K. Ounnunkad, S. Themsirimongkon, N. Promsawan, P. Waenkaew, S. Saipanya, Efficiency of bimetallic PtPd on polydopamine modified on various carbon supports for alcohol oxidations, Chem. Phys., 483484 (2017) 56-67.

40. M. Lin, X. Hu, Z. Ma, L. Chen, Functionalized polypyrrole nanotube arrays as electrochemical biosensor for the determination of copper ions, Analytica Chimica Acta, 746 (2012) 63-69.

41. S. Y. Huang, P. Ganesan, B.N. Popov, Development of conducting polypyrrole as corrosion-resistant catalyst support for polymer electrolyte membrane fuel cell (PEMFC) application, Appl Catal B-Environ, 93 (2009) 75-81.

42. G. Wu, L. Li, J. H. Li, B. Q. Xu, Methanol electrooxidation on Pt particles dispersed into PANI/SWNT composite films, $J$ Power Sources, 155 (2006) 118-127.

43. M. S. Çelebi, K. Pekmez, Electrooxidation of Formic Acid Using Pt Nanoparticles Supported on Conducting Poly(Vinylferrocene) Polymer Support, Hacettepe J. Biol. \& Chem., 45 (2017) 351-358.
44. M. S. Çelebi, K. Pekmez, H. Özyörük, A. Yildiz, Preparation and physical/electrochemical characterization of $\mathrm{Pt} /$ poly(vinylferrocenium) electrocatalyst for methanol oxidation, J. Power Sources, 183 (2008) 8-13.

45. M. S. Çelebi, K. Pekmez, H. Özyörük, A. Yildiz, Electrochemical synthesis of Pd particles on poly(vinylferrocenium), Catal. Commun., 9 (2008) 2175-2178.

46. W. Ye, H. Kou, Q. Liu, J. Yan, F. Zhou, C. Wang, Electrochemical deposition of Au-Pt alloy particles with cauliflower-like microstructures for electrocatalytic methanol oxidation, Int. J. Hydrogen Energy, 37 (2012) 4088-4097.

47. M. F. Hossain, J. Y. Park, Amperometric glucose biosensor based on Pt-Pd nanoparticles supported by reduced graphene oxide and integrated with glucose oxidase, Electroanalysis, 26 (2014) 940-951.

48. X. Quan, Y. Mei, H. Xu, B. Sun, X. Zhang, Optimization of Pt-Pd alloy catalyst and supporting materials for oxygen reduction in air-cathode microbial fuel cells, Electrochim. Acta, 165 (2015) 72-77.

49. X. Yan, T. Liu, J. Jin, S. Devaramani, D. Qin, X. Lu, Well dispersed Pt-Pd bimetallic nanoparticles on functionalized graphene as excellent electro-catalyst towards electrooxidation of methanol, J. Electroanal. Chem., 770 (2016) 33-38.

50. C. Aso, T. Kunitake, T. Nakashima, Cationic polymerization and copolymerization of vinylferrocene, Die Makromolekulare Chemie: Macromolecular Chemistry and Physics, 124 (1969) 232-240.

51. P. J. Peerce, A. J. Bard, Polymer films on electrodes. Part II. Film structure and mechanism of electron transfer with electrodeposited poly(vinylferrocene), J. Electroanal. Chem., 112 (1980) 97-115.

52. M. S. Çelebi, H. Özyörük, A. Yıldız, S. Abacı, Determination of $\mathrm{Hg} 2+$ on poly (vinylferrocenium)(PVF+)-modified platinum electrode, Talanta, 78 (2009) 405-409.

53. A. J. Gregory, W. Levason, R. E. Noftle, R. Le Penven, D. Pletcher, Studies of platinum electroplating baths Part III. The electrochemistry of $\mathrm{Pt}(\mathrm{NH} 3) 4-\mathrm{x}(\mathrm{H} 2 \mathrm{O}) 2+\mathrm{x}$ and $\mathrm{PtCl} 4-$ $x(\mathrm{H} 2 \mathrm{O}) \times 2-x-$, J. Electroanal. Chem., 399 (1995) 105-113.

54. C. R. K. Rao, D.C. Trivedi, Chemical and electrochemical depositions of platinum group metals and their applications, Coord. Chem. Rev., 249 (2005) 613-631. 